\title{
VEGETATIVE ANATOMY OF THE ORCHID BULBOPHYLLUM STERILE (ORCHIDACEAE: EPIDENDROIDEAE)
}

\author{
Muthukumar T. ${ }^{1,2} \&$ Shenbagam M. ${ }^{1}$ \\ ${ }^{1}$ Root and Soil Biology Laboratory, Department of Botany, Bharathiar University, Coimbatore 641046, \\ Tamilnadu, India \\ ${ }^{2}$ Corresponding author: tmkum@yahoo.com
}

\begin{abstract}
The anatomical characteristics of leaf, pseudobulb, and root of Bulbophyllum sterile of the subfamily Epidendroideae (Orchidaceae) were investigated. The anatomical investigation involved observing sections after staining with different stains as well as scanning electron microscopy. Additionally, the cell dimensions were also measured. The amphistomatic leaves of $B$. sterile had a thick cuticle, paracytic type of stomata, collateral vascular bundles and starch grains. The rhizome had cuticularized uniseriate epidermis and a single layer of the hypodermis. The parenchymatous stem ground tissue was distinguished into outer and inner regions separated by a band of sclerenchymatous tissue. Collateral vascular bundles were distributed in the inner ground tissue. The size of the vascular bundles generally increased from the periphery towards the center. A sclerenchymatous patch covered the phloem pole, whereas the xylem is covered by thin walled parenchymatous cells. The outer surface of the pseudobulb is covered by a thick cuticle. The parenchymatous ground tissue consisted of starch grains, aeration, water and algal cells and scattered collateral vascular bundles. Sclerenchymatous cells covered the phloem pole, whereas the xylem is covered by thin-walled cells. The velamen in $B$. sterile is single layered consisting of highly elongated compactly arranged cells. Uniseriate exodermis is dimorphic consisting of long and short cells. Cortical cells are differentiated into exodermis and endodermis. The O-thickened endodermal cell layer is interrupted by thin walled passage cells. Pith is sclerenchymatous. From this study, it can be concluded that $B$. sterile possess anatomical adaptations to xeric conditions in all the vegetative organs.
\end{abstract}

KEY wORDS: pseudobulb, raphides, rhizome, velamen, xerophyte

Introduction. Described by Thouars in 1822, the genus Bulbophyllum belonging to the subfamily Epidendroideae, is the second largest genera of flowering plants with more than 2000 species next only to Astragalus of Fabaceae (Smidt et al. 2007, Govaerts et al. 2017). With Papua New Guinea as the center of diversity, taxa of this genus are pantropical spreading across Africa, Australia, India, Madagascar, Southeast Asia, and in tropical South and Central America (Dressler 1990). In India, this genus is represented by over 100 species of which 75 species occur in north-eastern India (Misra 2007). Although 4-5 species of Bulbophyllum were reported previously by Hooker (1894) and Fischer (1928) from South India, Abraham \& Vatsala (1981) reported seven species of Bulbophyllum endemic to peninsular India. However, Henry et al. (1989) listed 11 species of Bulbophyllum in their list of angiosperms occurring in the south Indian state of Tamilnadu, India.

Investigations on the vegetative anatomy of Bulbophyllum dates back to 1856 when Chatin examined the structure and function of roots in several orchids including Bulbophyllum careyanum (Hook.) Spreng (Stern 2014b). Anatomical studies on Bulbophyllum were reviewed by Stern et al. (2014b). Piazza et al. (2015) recently compared the vegetative anatomy of 13 species of epiphytic or rupicolous Bulbophyllum belonging to sections Didactyle and Xiphizusa to identify the anatomical characters that would be useful in differentiating species between and among the sections and the adaptations of the species to the xeric environments. The results of the study revealed certain anatomical variation among the species of the two sections. Moreover, the study 
also indicated the lipophilic secretion by the trichomes of the young leaves and the presence of common xeromorphic characters among the species of the two sections.

An examination of the leaf anatomy of 14 Bulbophyllum species of the section Micranthae and its comparison with the results of the molecular analysis revealed that the anatomical characters and the molecular analysis may complement each other in developing phylogenetic hypotheses (Smidt et al. 2013). The leaf anatomy of $B$. dissitiflorum Seidenf., B. appendiculatum (Rolfe) J.J.Sm. and B. gamblei (Hook.f.) Hook.f. was studied by Chowlu et al. (2015) while examining the extended distribution of these species in India. All the three species had cuticle of varying thickness, polygonal epidermal cells, heterogeneous mesophyll, hypostomatic stomata distribution and wax secreting cells and multicellular glandular hairs on both the leaf surfaces (Chowlu et al. 2015). In spite of the long history, anatomical investigations on Bulbophyllum are limited to a small percentage of species when compared to the number of species constituting the genus.

The epiphytic orchid Bulbophyllum sterile (Lam.) Suresh (=Bulbophyllum neilgherrens Wight) is distributed in Bangladesh, peninsular India, Nepal, and Myanmar, and is the commonest species of Bulbophyllum found in South India (Abraham \& Vatsala 1981, Jose \& George 2015). It occurs in a wide range of elevations ranging from plains up to $900 \mathrm{~m}$ (Abraham \& Vatsala 1981). There is a wide variation in flower colour and arrangement depending on the altitude (Abraham \& Vatsala 1981).

Bulbophyllum species have many medicinal and artistic uses in Africa and Asia (Lawler 1984). In China, some species are used to treat primary tuberculosis and stomach cancer (Pridgeon et al. 2014). The pseudobulbs are used as a tonic for rejuvenation (Jonathan \& Raju 2005, Teoh 2016). In India, the chopped pseudobulbs of B. sterile are boiled in coconut oil and applied to cure rheumatism (Shanavaskhan et al. 2012). The extract prepared from the pseudobulbs of $B$. sterile sold in the name of Purusharantha are used as a tonic as well as for the restoration of adolescence (Chowdhery et al. 1998, Roy et al. 2007, Hossain 2009). The fine paste prepared from the leaves and pseudobulbs of $B$. neilgherrense Wight ( $=B$. sterile) is taken orally for treating leucoderma and heart diseases (Rajendran et al. 1997, Harshitha et al. 2013). A recent study on the active fractions of pseudobulbs and roots of $B$. sterile for antitumor activities suggested that the active fractions of bulbs and roots possessed anticancer activity (Biswas et al. 2016). The medicinal value of $B$. sterile has resulted in the large-scale unsustainable harvest of plants from the wild in Western Ghats region of southern India. Though the therapeutic value of $B$. sterile is well recognized, the anatomical aspects of this species are not known. Further, it is also important to understand the adaptations of $B$. sterile for its wide range of occurrence in different types of environments. Therefore, the aim of the present study is to investigate the anatomical features of different vegetative organs of $B$. sterile and to identify the anatomical adaptations of this species that enable it to survive in the arid epiphytic conditions.

Materials and methods. Three plants of $B$. sterile (Fig. 1A-B) were collected from a home garden in Coimbatore $\left(11^{\circ} 04^{`} \mathrm{~N}\right.$ to $\left.76^{\circ} 93^{`} \mathrm{E}\right)$ during January 2017. The elevation of Coimbatore is 426 to $550 \mathrm{~m}$ a.s.1 and the annual rainfall varies from 500 to 700 $\mathrm{mm}$. The leaf, rhizome, bulb, and root of the fresh plants were used for the anatomical studies. The plant materials were washed with distilled water and used or fixed in FAA (Formalin-Acetic Acid-70\% ethanol) solution until processing.

For light microscopy, the fresh/preserved plant materials were hand sectioned using a razor blade (transverse sections, 25-30 $\mu \mathrm{m}$ ) and stained with safranin. Other stains and histological reagents like Sudan IV (lamellar suberin), Toluidine blue/ $\mathrm{HCl}-$ phloroglucinol (lignin and tannin), and Iodine (starch) were also used to detect the presence of specific histochemical (Johansen 1940). The complete thin sections were used for the evaluation of plant structural parameters. Stained sections were mounted in glycerine on microscopic slides and observed under a BX 51 light microscope. In addition to the general observations, size of parts or cell length and width or layers were recorded or measured using a calibrated ocular scale in leaves (stomata length and width and pore size, epidermis, mesophyll), pseudobulb (epidermis), rhizome (epidermis, ground tissue, 

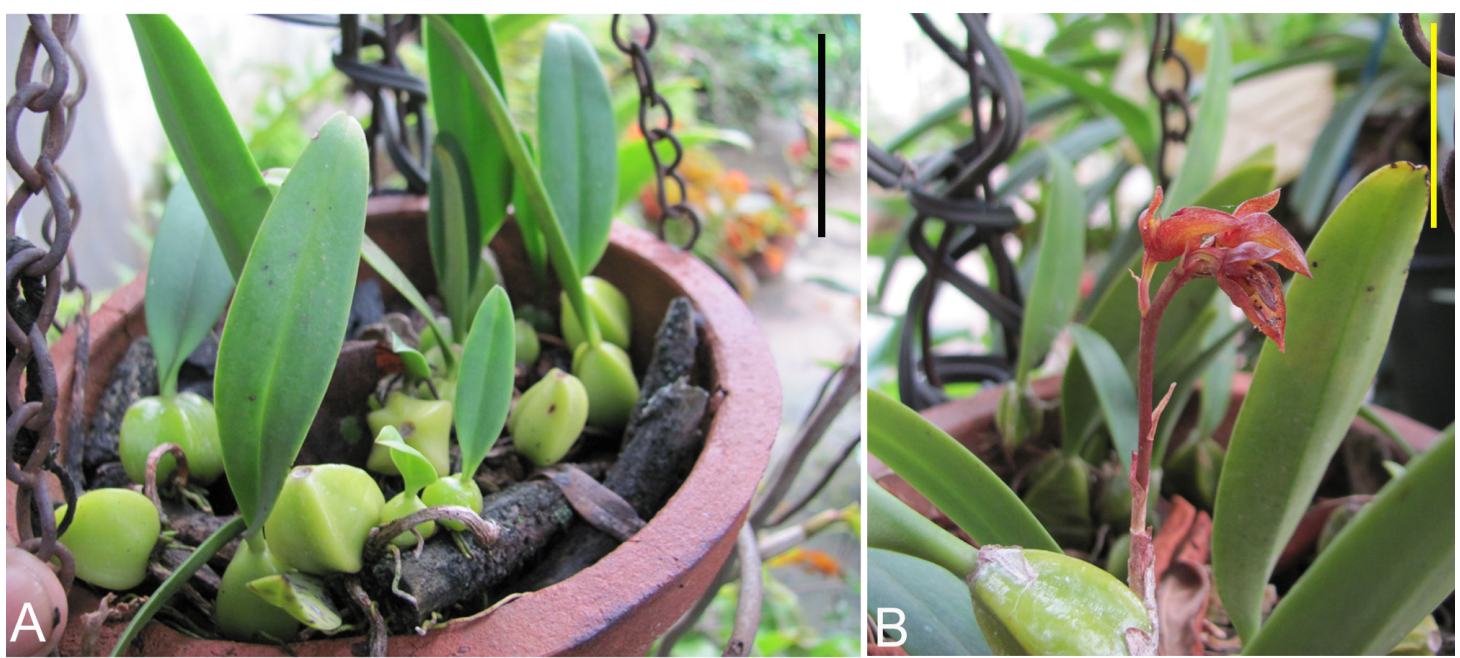

FigURE 1. Habit of Bulbophyllum sterile showing vegetative parts (a) and the inflorescence axis (b). Scale bars $=5 \mathrm{~cm}$.

vascular bundle) and roots (velamen, exodermis, cortex, endodermis, xylem arches). The measured values are presented either as range or length (mean \pm standard error $) \times$ width (mean \pm standard error) or mean \pm standard error. Images of the sections were photographed using a ProgRes3 camera attached to an Olympus BX 51 light microscope. Stomatal index (\%) was calculated $(n=10)$ from the number of epidermal cells and stomata in ten randomly selected microscopic fields (×200) according to Salisbury (1927).

For scanning electron microscopy (SEM) a section of $5 \mathrm{~mm}^{2}$ of leaf lamina or thin transverse section of pseudobulb, rhizome, and root was fixed on to double sided adhesive tape onto labeled stubs. The specimens were coated with gold and scanned in Philips SEM 515 Scanning electron microscope. For epidermal studies, samples were taken from midway between the base and apex of the lamina.

Data on the stomatal index was subjected to paired $t$ - test to assess the significance of variation in the distribution of the stomata on the adaxial and abaxial leaf surfaces.

\section{Results}

Leaf (Fig. 2 A-H).- Superficial view. The leaves are covered by a $4 \mu \mathrm{m}$ thick cuticle which is wrinkled and present both on the adaxial and abaxial surfaces. Stomata are more numerous $\left(t_{10}=-8.456 ; P<0.001\right.$; $\mathrm{n}=10)$ on the abaxial $(9.44 \pm 0.40)$ than the adaxial
$(5.24 \pm 0.394)$ surface. The stomata are tetracytic where the 2 guard cells are surrounded by four subsidiary cells. Chloroplasts present in guard cells. The stomatal pore measures $20.35 \pm 0.35 \times 18.55 \pm 0.18 \mu \mathrm{m}$. The guard cells measures $36.05 \pm 0.27 \times 11.65 \pm 0.17 \mu \mathrm{m}$ and subsidiary cells measures $59.65 \pm 0.34 \times 22.00 \pm 0.47$ $\mu \mathrm{m}$. Hairs absent.

Cross section. Upper and lower epidermis uniseriate, compactly arranged, rectangular, thickwalled cells, nucleate and parenchymatous. Cells of the upper epidermis measure $46.2 \pm 0.45 \times 24.25 \pm 0.45 \mu \mathrm{m}$ and those of the lower epidermis measure $47.3 \pm 0.47$ $\times 28.1 \pm 0.31 \mu \mathrm{m}$. Hypodermis and fibrous bundles absent. Mesophyll homogenous not differentiated into palisade and spongy cells but are rich in chlorophyll. The number of cell layers in the mesophyll varies from 34-38 (average $36.45 \pm 0.23$ ). The mesophyll contains pitted and striated idioblasts and air cells. The vascular bundles are arranged in a single row in the middle. The largest vascular bundle is present in the midrib region. In the lamina, a large vascular bundle alternates 2-3 smaller vascular bundles. The vascular bundles are collateral and surrounded by a distinct bundle sheath. Both xylem and phloem poles are covered by a sclerenchymatous patch.

Pseudobulb (Fig. 3A-H).- The bulb is green in colour and ridged. The surface of the bulb is covered by a $4-5 \mu \mathrm{m}$ thick cuticle. Stomata are absent. The epidermis is uniseriate with thin walled 


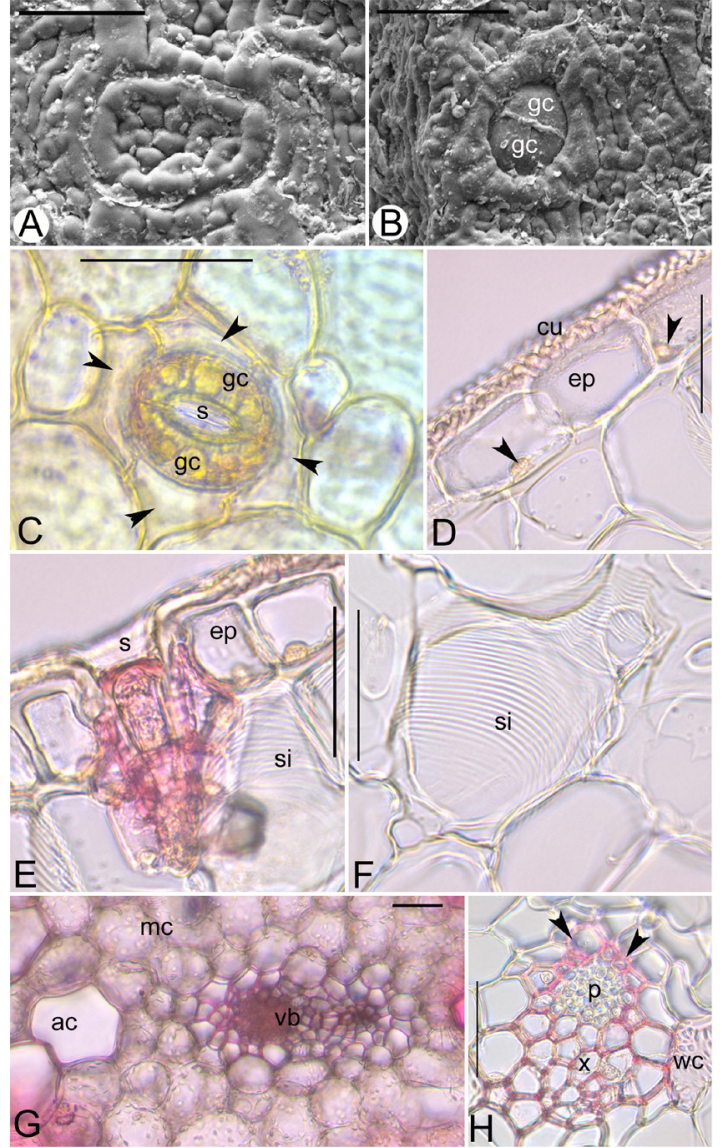

FIGURE 2. Leaf anatomy of Bulbophyllum sterile. A.

Scanning electron microscope (SEM) view of the adaxial leaf surface, B. SEM view of the stomata and guard cells. C. Adaxial leaf surface showing stomatal pore (s), guard cells (gc) and four subsidiary cells (arrow heads), D. T.S. of leaf showing epidermis (ep), cuticle (cu), and nucleus (arrow heads); E. epidermis (ep) and striated idioblast (si), F. Striated idioblast cells with secondary thickenings (si), G. Aeration cell (ac), homogenous mesophyll (mc) and vascular bundle (vb), H. Collateral vascular bundle with phloem (p), xylem (x), Sclerenchymatous patch (arrow heads) and water cells with secondary thickenings (wc). Scale bars $=30 \mu \mathrm{m}(\mathrm{A}), 50 \mu \mathrm{m}(\mathrm{B}-\mathrm{H})$.

rectangular cells measuring $25.15 \pm 0.3 \times 9.25 \pm$ $0.16 \mu \mathrm{m}$. Hypodermis is absent. The ground tissue is parenchymatous consisting of starch grains, raphides, spherical stegmata and druse crystals (calcium oxalate crystals), aeration and algal cells. Pitted water cells are also associated with the mesophyll. The vascular bundles are scattered in the ground

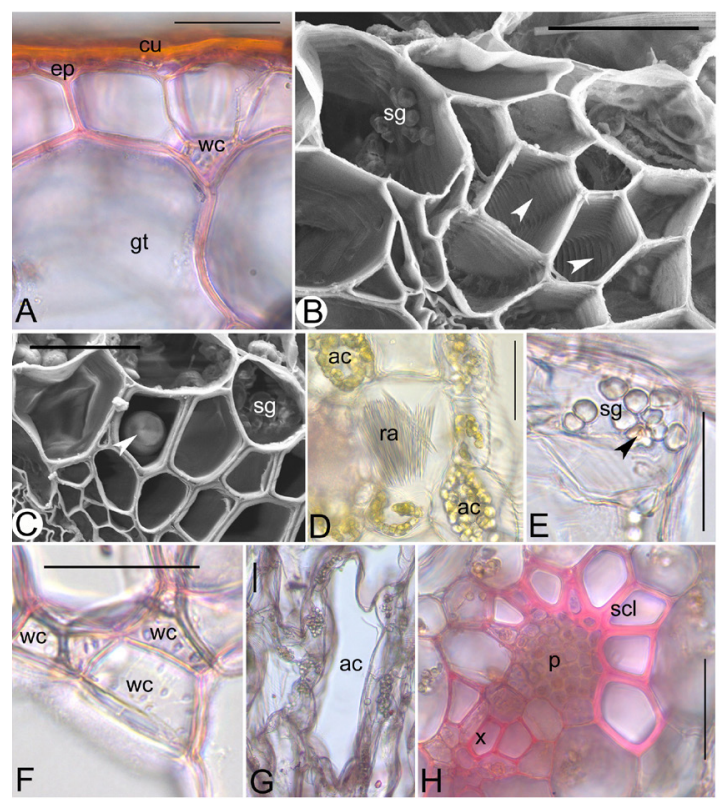

Figure 3. Pseudobulb anatomy of Bulbophyllum sterile. A. T.S of pseudobulb showing epidermis(ep) covered with a cuticle (cu), and water cell with thickening (wc) in the ground tissue (gt), B. SEM of pseudobulb TS showing ground tissue cells with ladder-like thickenings (arrow heads) and starch grains (sg), C. Spherical calcium oxalate crystal (arrow head) and starch grains (sg) in the ground cells, D. Raphides (ra) and algal cells (ac) in the ground tissue, E. Starch grains ( $\mathrm{sg}$ ) and druse crystal (arrow head) in a single cell, F. Band of pitted water cells (wc), G. Aeration cell (ac) in the ground tissue, H. Vascular bundle with xylem (x), phloem (p) and sclerenchymatous tissue (scl). Scale bars $=30 \mu \mathrm{m}(\mathrm{B}$, C); $50 \mu \mathrm{m}(\mathrm{A}, \mathrm{E}-\mathrm{H})$.

tissue and collateral. Sclerenchymatous cells cover the phloem pole, whereas the xylem is covered by thin-walled cells.

Rhizome (Fig 4. A-F). - The rhizome is cylindrical and brown. It is covered by a cuticle that is $4-5 \mu \mathrm{m}$ thick and contoured. The epidermis is uniseriate, comprising compactly arranged oblong shaped parenchymatous cells measuring $114.3 \pm 2.79 \times$ $29.00 \pm 0.45 \mu \mathrm{m}$. Ground tissue is parenchymatous and distinguished into outer and inner regions. The two regions of the ground tissue are separated by a sclerenchymatous band that is 3-6 layered. Starch grains are present in the ground tissues. Outer ground tissue region consists of 17-20 layers of angular 


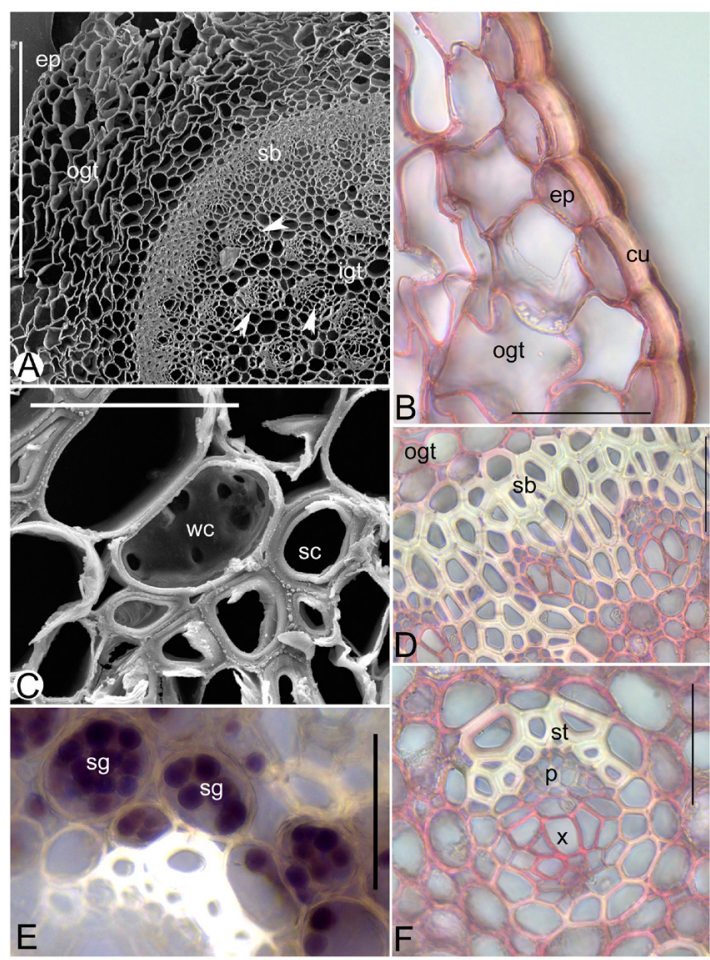

FiguRE 4. Rhizome anatomy of Bulbophyllum sterile. A. Scanning electron microscope (SEM) of rhizome TS showing epidermis (ep), outer ground tissue (ogt), sclerenchymatous band ( $\mathrm{sb}$ ), inner ground tissue (igt) and vascular bundles (arrow heads), B. Thick cuticle (cu), epidermis (ep) and parenchymatous outer ground tissue (ogt), C. SEM of rhizome TS showing pitted water storage cell (wc) and sclerenchyma cell (sc), D. Parenchymatous outer ground tissue (ogt) and sclerenchymatous band (sb), E. Starch grain (sg) filled cells surrounding the vascular bundle, F. Vascular bundle showing xylem (x), phloem (p) and sclerenchymatous tissue (st). Scale bars $=30 \mu \mathrm{m}(\mathrm{C})$, $50 \mu \mathrm{m}$ (B, D-F), $400 \mu \mathrm{m}$ (A).

parenchymatous cells and vascular bundles are absent in this region. The inner ground tissue is also parenchymatous with isodiametric cells and contains vascular bundles in the scattered form. The size of the vascular bundles generally increases from the periphery towards the center. The vascular bundles are collateral and measures $87.25 \pm 0.29 \times 74.00 \pm 0.18$ $\mu \mathrm{m}$. A sclerenchymatous patch covers the phloem pole, whereas the xylem is covered by thin walled parenchymatous cells. Parenchymatous cells adjacent to the sclerenchymatous patch are packed with starch grains that stain brown with iodine.

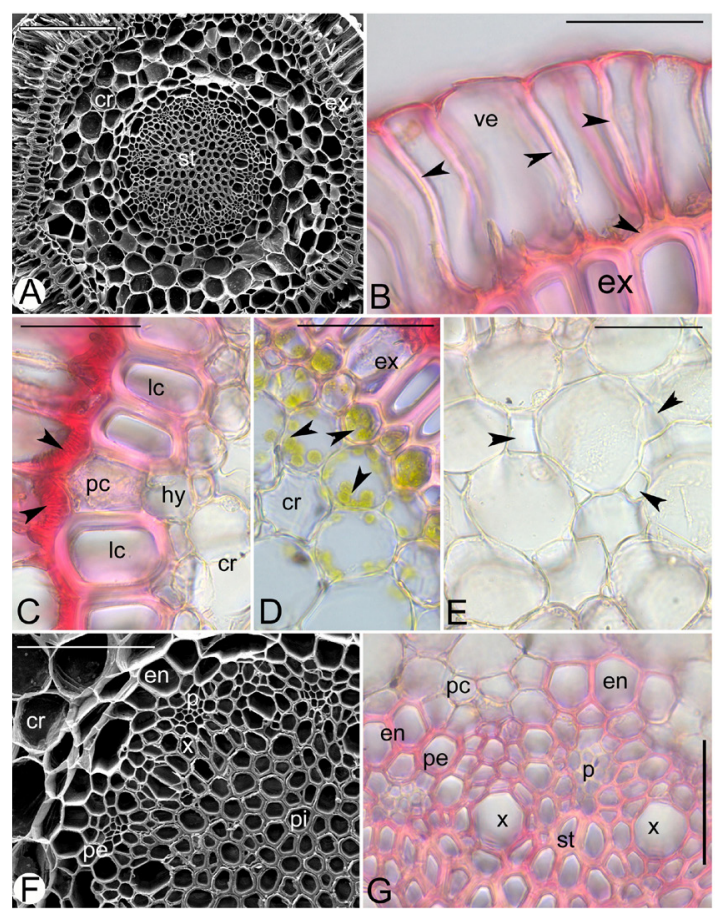

FIgURE 5. Root anatomy of Bulbophyllum sterile. A. Scanning electron microscope (SEM) of root TS showing velamen (v), exodermis (ex), cortex (cr) and stele (st), B. Velamen cells (ve) with thickened radial and inner periclinal walls (arrow heads) and exodermis (ex), C. Tilosomes (arrow heads), long (lc) and passage cells of the exodermis (pc) of the exodermis, layer of small parenchymatous cells (hy) and cortex (cr), D. Exodermis (ex) and cells of the cortex (cr) containing chlorophyll (arrow heads), E. Aerenchyma cells with squarish, triangular and circular intercellular spaces (arrow heads), F. SEM of the root TS showing cortex (cr), endodermis (en), pericycle (pe), xylem (x), phloem (p) and sclerenchymatous pith (pi), G. Vascular bundle showing O-thickened endodermal cells, passage cells (pc), pericycle (pe) and xylem (x) and phloem (p) embedded in sclerenchymatous tissue. Scale bars $=50$ $\mu \mathrm{m}$ (B-E, G), $100 \mu \mathrm{m}$ (F), $400 \mu \mathrm{m}$ (A).

Root (Fig 5. A-G).- The roots are cylindrical and covered by a layer of velamen. Root hairs absent. The cells of the velamen are highly elongated and compactly arranged without any thickenings. The velamen cells measure $95.85 \pm 0.43 \times 26.03 \pm 0.50 \mu \mathrm{m}$. The radial and inner periclinal walls of the velamen cells are much thickened than the outer periclinal walls. The velamen is followed by a uniseriate exodermis that is dimorphic consisting of long and short cells. The cells of the 
exodermis are much smaller than those of the velamen. Cover cells absent, but broadly lamellate tilosomes present. Long cell measures $43.04 \pm 0.49 \times 21.85 \pm 0.46$ $\mu \mathrm{m}$, walls O-thickened; short cells are $3 / 4$ of the long cells and thin walled. The cortex is parenchymatous with intercellular spaces that are squarish, triangular or circular and 4-10 layered. Outer one to two layers of the cortical cells are smaller than rest of the cortical cells and often contain chloroplasts. The cells of endodermis measure $21.25 \pm 0.34 \times 19.95 \pm 2.06 \mu \mathrm{m}$ and are O-thickened. The thick walled endodermal cell layer is interrupted by the presence of one to three thin walled passage cells. The cells of the pericycle are thick walled opposite to the phloem and thin walled opposite to the xylem. The number of xylem arches ranges from 7-11 (average $8.90 \pm 0.43$ ). The xylem and phloem elements are embedded in the sclerenchymatous tissue. The pith is sclerenchymatous. Cell inclusions like starch grains or cell modifications like the water cells or air cells absent.

Discussion. During the course of evolution, tropical orchids have developed several adaptations to grow in highly stressful epiphytic habitats. The extreme environmental conditions induce a large number of physiological changes in plants which result in modifications in the structure of the vegetative organs (Stern 2014a, Yang et al. 2016). Generally, plants that thrive in extreme environmental conditions have one or more types of adaptation that help them to cope up the stresses. The anatomical modification is one of the most common strategy plants adapt to grow in extreme habitats (Hlwatika \& Bhat 2002). Although certain characteristics are common for plants growing in the stressed habitats, species of the same genus may adopt different strategies for the same environment (Piazza et al. 2015).

The vegetative anatomy of $B$. sterile exhibited variation in certain aspects compared to other Bulbophyllum species and adaptations to xeric conditions of the epiphytic habitats in all the organs analyzed. Though hairs of various natures were reported on leaf surfaces in several species of Bulbophyllum, hairs were completely absent in leaves of B. sterile (Gravendeel et al. 2014). The leaf surface was peculiar presenting a cobblestonelike arrangement. These wrinkly leaf surfaces in $B$. sterile were not the result of the bulging of the outer periclinal walls of the epidermal cells, but the varied deposition of the cuticle as evidenced by the cordlike appearance in transverse section. The thickness of the leaf cuticle in B. sterile is almost similar to those reported for Dendrobium chrysotoxum Lindl., and Dendrobium officinale Kimura \& Mego which are shown to have reduced transpiration rates (Yang et al. 2016). These observations confirm the fact that cuticle may act as an efficient barrier in preventing water loss from plants. The amphistomatal nature of $B$. sterile leaves is in contrast to the hypostomatal nature reported in other species of Bulbophyllum (Smidt et al. 2013, Stern 2014a, b, Piazza et al. 2015). Generally in angiosperms, hypostomatal leaves are prevalent in mesophytic species, whereas species growing in environments that are extremely dry or humid have amphistomatal leaves (Stancato et al. 1999, Parkhurst 1978). Nevertheless, when amphistomatal nature occurs, the number of stomata is less on the adaxial surface than the abaxial surface as observed in $B$. sterile. The uniseriate epidermis of $B$. sterile leaf consisted of rectangular parenchymatous cells with uniform thickened walls in contrast to the irregularly polygonal cells with variedly thickened walls reported in some species of Bulbophyllum (Piazza et al. 2015).

The presence of spiral idioblasts and air cells in B. sterile can be due to their habitat. This explains for the thick and fleshy nature of the leaves. Olatunji \& Nengim (1980) termed these water storage cells as tracheoidal elements. Tracheoidal idioblasts usually occur when plants are associated with dry environments (Olatunji \& Nengim 1980). According to Pridgeon \& Stern (1982), during the shortage of water, these cells either get filled with air or may become involved in water storage. Otherwise, they play a role in the mechanical support of adjacent tissues (Aybeke et al. 2010). In the present study, the water storage cells are pitted or striped. Kaushik (1983) observed simple and special water storage cells in many Himalayan orchids. Nevertheless, the absence of hypodermis in B. sterile simulated the study of Stern \& Carlsward (2009), where the members of the sub tribe Laeliinae were characterized by the absence of hypodermis. The homogenous nature of mesophyll cells in B. sterile is supported 
by the studies of Stern \& Carlsward (2009) as well as Mohana Rao \& Khasim (1987) and Gravendeel et al. (2014).

The rhizome tissues in orchids have a specialized function of absorbing water from the roots, leaves, and stem succulence (Benzing et al. 1983, Moreira \& Isaias 2008). The rhizome in B. sterile revealed a thick contoured cuticle similar to cell height followed by a uniseriate epidermis consisting of compactly arranged parenchymatous cells contrary to the observations of Mohana Rao \& Khasim (1987) where the epidermal cells were tubular in Bulbophyllum andersonii (Hook. f.) J.J. Sm., and Bulbophyllum dyerianum (King \& Pantl.) Seidenf. The ground tissue was differentiated into outer and inner regions, separated by sclerenchymatous band. This contrasts the results of Mohana Rao \& Khasim (1987) where such sclerenchymatous bands were absent in Bulbophyllum species examined. The phloem pole in $B$. sterile was covered by a sclerenchymatous band contrary to the xylem which was covered by thin walled parenchymatous cells. Sclerenchymatous bundle caps were observed in the rhizomatous taxa studied by Aybeke et al. (2012) namely Cephalanthera epipactoides Fisch. \& C.A. Mey, Cephalanthera longifolia (L.) Fritsch, and Epipactis helleborine (L.) Crantz. The presence of abundant starch grains in the inner ground tissues surrounding the vascular bundles is unique to this species which aids in the function of storage.

The pseudobulb of $B$. sterile is ovoid and covered by a thick cuticle as in B. occultum Thouras, and B. lobbii Lindl. (Stern 2014b). The thin-walled rectangular cells in the epidermis contrast the observations of Mohana Rao \& Khasim (1987) where the cells were squarish and turgid. However, Mohana Rao \& Khasim (1987) reported that in B. andersonii and B. dyerianum, some mesophyll cells change into columnar and club-shaped cells having multi-spiral cellulosic thickenings to function as water storage cells whereas $B$. leopardianum (Wall.) Lindl. ex Wall. is characterized by simple and special water storage cells. In the present study, the water storage cells in the pseudobulb of $B$. sterile were pitted. Moreover, the ground tissue also contained starch grains, raphides, aeration and algal cells which were not observed in any of the three Bulbophyllum species examined by Mohana Rao \& Khasim (1987).
The sclerenchymatous band in B. sterile that separates the outer and inner ground tissue is much wider than the 1-2 layer of sclerenchymatous band reported in other species of Bulbophyllum (Stern 2014b). Thick-walled sclerenchyma cells adjacent to phloem and xylem subtended by thin-walled, polygonal parenchyma cells were also observed in Gramatophyllum (Yukawa \& Stern 2002). The parenchymatous bridge in the vascular bundles reported in other species of Bulbophyllum (Stern 2014b) was however absent in B. sterile.

The thin roots of $B$. sterile are cylindrical whereas the roots attached to the substratum are flattened at the point of contact and lacked root hairs. The velamen of B. sterile is typical of Bulbophyllum type proposed by Porembski \& Barthlott (1988). The velamen is single layered composed of highly elongated cells that are compactly arranged unlike in Bulbophyllum weddellii (Lindley) Rchb.f., where it is two layered (Piazza et al. 2015). The outer periclinal wall of the velamen cells is much thinner than the inner periclinal and radial walls. Further, the stabilizing wall thickenings of the velamen cells are absent in roots of B. sterile as in other Bulbophyllum species (Porembski \& Barthlott 1988). It is often suggested that the size of the velamen could be related to specific environmental factors like temperature and water. Hence the species occurring in dry habitats or exposed habitats have a multilayered velamen while those like Bulbophyllum that occur in humid environments are characterized by a single layered velamen (Sanford \& Adanlawo 1973). The velamen is an important structure in orchid roots adapted for the uptake of water and nutrients in conditions of drought. It helps in the quick absorption of water and prevents moisture loss from the roots, apart from providing mechanical protection, reflecting infra- red radiation, screening of roots against ultraviolet radiation and absorbing immobilized nutrients from rain water (Muthukumar \& Kowsalya 2017). Apart from this, the other functions that can be attributed to this tissue include amplifying access to mineral-rich solutions (Benzing et al. 1982), and exchange of oxygen and carbon dioxide between the root and atmosphere (Moreira \& Isaias 2008).

The exodermis being the outer layer of the cortex (Engard 1944) consisted of long and short cells. Though the thick secondary wall development in long cells renders the cells dead at maturity (Pridgeon 
1986), nucleus was observed in some long cells of $B$. sterile exodermis. The deposition of lignin and suberin in the exodermal cell walls empower these cells to give mechanical protection and to maintain a layer of high humidity around the cortex (Sanford \& Adanlawo 1973, Benzing et al. 1983, Moreira \& Isaias 2008). In the present study, B. sterile had O- thickenings in their large cells. In contrast, the exodermis of $B$. involutum Borba, Semir \& F.Barros, B. medusa (Lindl.) Rchb.f., and $B$. perii Schltr. has been reported to possess $\cap$-thickened walls or variable wall thickening has been reported in B. imbricatum Lindl. (Stern 2014b, Piazza et al. 2015). The short passage cells of the exodermis are thin walled and living cells. These cells play a significant role in the nutrition and hydration of the epiphytic orchids (Stern 2014b).

Like in other species of Bulbophyllum, tilosomes of B. sterile was broadly lamellate (Pridgeon et al. 1983). In contrast, spongy tilosomes have been reported in Bulbophyllum micholitzianum Kranzl., and Bulbophyllum ornatissimum (Rchb.f.) J.J.Sm (Stern 2014b). This same author suggests that tilosomes in Bulbophyllum might have arose several times independently and at least once in tropical Asia, Africa, and the Neotropics possibly after the emergence of the epiphytic habit. This suggestion was based on the consistency in the morphology of tilosomes in this genus. Though not well resolved, tilosomes are presumed to play an important role in reducing transpiration in arid and exposed conditions. In addition, tilosomes are also believed to aid the movement of water into the root cortex when velamen is completely soaked with water (Pridgeon et al. 1983).

Raphides and water cells were present in the parenchymatous root cortex of $B$. sterile as in other Bulbophyllum species. Although raphides were present in root cortical cells, prismatic and druses of calcium oxalate crystals reported in some Bulbophyllum species were absent in the roots of $B$. sterile (Piazza et al. 2015). Generally, the fungal peloton was detected only in the cortical region that was that were opposite to the root portion that was attached to the substrate. The endodermal cells had O-thickened walls typical of Bulbophyllum species. The exodermal and endodermal wall thickening was considered as an adaptation to the epiphytic habit to prevent water loss from the cortical region and vascular cylinder (Moreira \& Isaias 2008).

LANKESTERIANA 18(1). 2018. C Universidad de Costa Rica, 2018.
The pericycle and pith are sclerenchymatous with thin walled pericycle cells opposite to xylem poles. Like many epiphytic orchids, the vascular tissues in $B$. sterile roots are embedded in sclerenchymatous tissues. This anatomical feature is considered to be a highly significant character that is related to the endurance of the plant during drought conditions (Nawaz et al. 2013, Muthukumar \& Kowsalya 2017). The number of xylem arches (9-12) is well within the range reported for Bulbophyllum species (Stern 2014b, Piazza et al. 2015). Nevertheless, experimental evidence is necessary to ascertain if $B$. sterile actually benefits from these anatomical modifications as recently shown for Dendrobium species by Yang et al. (2016).

Conclusions. Vegetative anatomy of B. sterile differs from other Bulbophyllum species in possessing leaves with a thick wrinkled cuticle, and amphistomatous distribution of stomata. The sclerenchymatous band in the rhizome of $B$. sterile is much wider than the 1-2 layered sclerenchyma band reported for other species of Bulbophyllum. Further, the major function of the rhizome appears to be storage as evidenced by the abundant starch grain filled cells of the inner ground tissue. In addition to these, B. sterile possessed anatomical adaptations to xerophytic conditions like the thick cuticle covering the whole aerial plant parts, amphistomatous condition, and special cells for water storage.

\section{LiTERATURE CITED}

Abraham, A. \& Vatsala, P. (1981). Introduction to orchids with illustrations and descriptions of 150 South Indian Orchids. TGBRI, Palode, Kerala, India.

Aybeke, M. (2012). Comparative anatomy of selected rhizomatous and tuberous taxa of subfamilies Orchidoideae and Epidendroideae (Orchidaceae) as an aid to identification. Plant Systematic Evolution, 298(9), 1643-1658. DOI: 10.1007/s00606-012-0666-9

Aybeke, M., Sezikb, E. \& Olgun, G. (2010). Vegetative anatomy of some Ophrys, Orchis and Dactylorhiza (Orchidaceae) taxa in Trakya region of Turkey. Flora, 205(2), 73-89. DOI: https://doi.org/10.1016/j. flora.2008.11.009

Benzing, D. H., Friedman, W. E., Peterson, G. \& Renfrow, A. (1983). Shootlessness, velamentous roots, and the pre-eminence of Orchidaceae in the epiphytic biotipe. American Journal of Botany, 70(1), 121-133. 
Benzing, D. H., Ott, D. W. \& Friedman, W. E. (1982). Roots of Sobralia macrantha (Orchidaceae): structure and function of the velamen-exodermis complex. American Journal of Botany, 69(4), 608-614.

Biswas, S., Pardeshi, R., Reddy, N. D., Shoja, M. H., Nayak, P. G., Manjunath Setty, M. \& Pai, K. S. R. (2016). Bulbophyllum sterile petroleum ether fraction induces apoptosis in vitro and ameliorates tumor progression in vivo. Biomedicine and Pharmacotherapy, 84, 14191427. DOI: 10.1016/j.biopha.2016.10.005

Chowdhery, H. J. (1998). Orchid flora of Arunachal Pradesh. Bishen Singh Mahaendra Pal Singh, Dehra Dun, India.

Chowlu, K., Sharma, H. B. \& Rao, A. N. (2015). Extended distribution of three Bulbophyllum species (Orchidaceae) in India and some observations about their foliar anatomy. Richardiana, 15, 168-182.

Dressler, R. L. (1990). The orchids, natural history and classification. Haward University Presss, London.

Engard, C. J. (1944). Morphological identity of the velamen and exodermis in orchids. Botanical Gazette, 105, 457462.

Fischer, C. E. C. (1928). Orchidaceae. In: J.S. Gamble (Ed.), Flora of Presidency of Madras. Vol. 8 (pp. 1399-1478). West, Newman and Adlard, London.

Govaerts, R., Bernet, P., Kratochvil, K., Gerlach, G., Carr, G., Alrich, P., Pridgeon, A. M., Pfahl, J., Campacci, M. A., Holland Baptista, D., Tigges, H., Shaw, J., Cribb, P., George, A., Kreuz, K. \& Wood, J. (2017). World Checklist of Orchidaceae. Facilitated by the Royal Botanic Gardens, Kew. http://apps.kew.org/wcsp/ (accessed 01 June 2017).

Gravendeel, B., Vermeulen, J. J., Fischer, G. \& Smidt, E. C. (2014). Bulbophyllum. In: A. M. Pridgeon, P. J. Cribb, M. W. Chase, F. N. Rasmussen (Eds.), Genera Orchidacearum, 6, Epidendroideae (Part Three) (pp. 4-41). Oxford University, Oxford.

Harshitha, K., Nishteswar, K. \& Harisha, C. R. (2013). Pharmacognostical and preliminary phytochemical investigations on different parts of Bulbophyllum neilgherrense Wight. - An orchid used in folk medicine. Global Journal of Research on Medicinal Plants and Indigenous Medicine, 2(4), 259-269.

Henry, A. N., Chithra, V. \& Balakrishnan, N. P. (1989). Flora of Tamil Nadu, India: Series I: Analysis. Vol. 3, Botanical Survey of India, Coimbatore, India.

Hlwatika, C. N. M., \& Bhat, R. B. (2002). An ecological interpretation of the difference in leaf anatomy and its plasticity in contrasting tree species in Orange Kloof, Table Mountain, South Africa. Annals of Botany, 89 (1), 109-114. DOI: 10.1093/aob/mcf011

Hooker, J. D. (1894). Flora of British India.vol VI Orchidaceae to Cyperaceae. L. Reeve \& Co., Ashford,
Kent, UK.

Hossain, M. M. (2009). Traditional therapeutic uses of some indigenous orchids of Bangladesh. Medicinal and Aromatic Plant Science and Biotechnology, 3(1), 100-106.

Johansen, D. A. (1940). Plant microtechnique. McGrawHill Book Co., New York, USA.

Jonathan, K. H. \& Raju, A. J. S. (2005). Terrestrial and epiphytic orchids of Eastern Ghats. EPTRI ENVIS Newsletter 11(3), 2-4.

Jose, M. \& George, K. V. (2015). Checklist of Orchids of Kottavasal Hills in Achancoil Forests, southern Western Ghats, (Kollam, Kerala), India. Journal of Threatened Taxa, 7(10), 7691-7696.

Kaushik, P. (1983). Anatomy of Aerides (Orchidaceae) and its ecological and taxonomical bearing. Phytomorphology, 32 (2,3), 157-166.

Lawler, L. J. (1984). Ethnobotany of the Orchidaceae. In: Arditti, J. (Ed.), Orchid biology reviews and prespectives, Vol. 3 (pp. 27-149), Cornell University Press, Ithaca.

Misra, S. (2007). Orchids of India: A glimpse. BishenSingh Mahendra Pal Singh, Dehra Dun, India.

Mohana Rao, P. R. \& Khasim, S. M. (1987). Anatomy of three species of Bulbophyllum (Orchidaceae) with comments on their ecological adaptability and taxonomy. Proceedings of the Indian Academy of Sciences, 97 (5), 391-397. DOI: doi:10.1007/BF03053565

Moreira, A. S. F. P. \& Isaias, R. M. S. (2008). Comparative anatomy of the absorption roots of terrestrial and epiphytic orchids. Brazilian Archives of Biology and Technology, 51(1), 83-93. DOI: https://dx.doi. org/10.1590/S1516-89132008000100011

Muthukumar, T. \& Kowsalya, A. (2017). Comparative anatomy of aerial and substrate roots of Acampe praemorsa (Rox.) Blatt. \& MC. Cann. Flora, 266, 1728. DOI: https://doi.org/10.1016/j.flora.2016.11.001

Nawaz, T., Hameed, M., Ashraf, M., Batool, S. \& Naz, N. (2013). Modifications in root and stem anatomy for water conservation in some diverse blue panic (Panicum antidotale Retz.) ecotypes under drought stress. Arid Land Research and Management, 27(3), 281-297. DOI: 10.1080/15324982.2012.727947

Olatunji, O. A. \& Nengim, R. O. (1980). Occurrence and distribution tracheoidal elements in the Orchidaceae. Botanical Journal of the Linnaean Society, 80(4), 357370. DOI: 10.1111/j.1095-8339.1980.tb01669.x

Parkhurst, D. F. (1978). The adaptive significance of stomatal occurrence on one or both surfaces of leaves. Journal of Ecology, 66 (2), 367-383. DOI: 10.2307/2259142

Piazza, L. D., Smidt, E. C. \& Bona, C. (2015). Anatomia comparada dos órgãos vegetativos de espécies de Bulbophyllum seção Didactyle (Lindl.) Cogn. e Bulbophyllum seção Xiphizusa Rchb.f. (Orchidaceae). 
Hoehnea, 42(1), 171-183. DOI: http://dx.doi. org/10.1590/2236-8906-34/2014

Porembski, S. \& Barthlott, W. (1988). Velamen radicum micromorphology and classification of Orchidaceae. Nordic Journal of Botany, 8(2), 117-137. DOI: 10.1111/ j.1756-1051.1988.tb00491.x

Pridgeon, A. M. (1986). Anatomical adaptations in Orchidaceae. Lindleyana, 1(2), 90-101.

Pridgeon, A. M. \& Stern, W. L. (1982). Vegetative anatomy of Myoxanthus (Orchidaceae). Selbyana, 7(1), 55-63. DOI: http://www.jstor.org/stable/41759565

Pridgeon, A. M., Cribb, P. J., Chase, M. W. \& Rasmussen, F. N. (2014). Genera Orchidacearum Volume 6: Epidendroideae, Part 3. OUP Oxford, U.K.

Pridgeon, A. M., Stern, W. L. \& Benzing, D. H. (1983). Tilosomes in roots of Orchidaceae: Morphology and systematic occurrence. American Journal of Botany, 70(9), 1365-1377.

Rajendran, A., Rama Rao, N., Ravikumar, K. \& Henry, A. N. (1997). Some medicinal orchids of southern India. Ancient Science of Life, 17(1), 10-14.

Roy, A. R., Patel, R. S., Patel, V. V. \& Yadav, D. S. (2007). Medicinal orchids of Meghalaya. The Journal of the Orchid Society of India, 21(1,2), 15-17.

Salisbury, E. J. (1927). On the causes and ecological significance of stomatal frequency, with special reference to the woodland flora. Philosophical Transactions of the Royal Society London B, 216, 1-65. DOI: $10.1098 /$ rstb.1928.0001

Sanford, W. W. \& Adanlawo, I. (1973). Velamen and exodermis characters of West African epiphytic orchids in relation to taxonomic grouping and habitat tolerance. Botanical Journal of the Linnaean Society, 66(4), 307321. DOI: $10.1111 / j .1095-8339.1973 . t b 02178 . x$

Shanavaskhan, A. E., Sivadasan, M., Alfarhan, A. H. \& Thomas, J. (2012). Ethnomedicinal aspects of angiospermic epiphytes and parasites of Kerala, India. Indian Journal of Traditional Knowledge, 11(2), 250258.

Smidt, E. C., Gallo, L. W. \& Scatena, V. L. (2013). Leaf anatomical and molecular studies of Bulbophyllum section Micranthae (Orchidaceae) and their implications for systematic. Brazilian Journal of Botany, 36(1), 7582. DOI: $10.1007 / \mathrm{s} 40415-013-0008-3$

Smidt, E. C., Silva-Pereira, V., Borba, E. L. \& Van den Berg, C. (2007). Richness, distribution and important areas to preserve Bulbophyllum in the Neotropics. Lankesteriana, 7(1-2), 107-113. DOI: 10.15517/lank. v7i1-2.18448

Stancato, G. C., Mazzoni-Viveiros, S. C., \& Luchi, A. E. (1999). Stomatal characteristics in different habitat forms of Brazilian species of Epidendrum (Orchidaceae). Nordic Journal of Botany, 19(3), 271275. DOI: 10.1111/j.1756-1051.1999.tb01110.x

Stern, W. L. (2014a). Anatomy of the Monocotyledons: X. Orchidaceae. University Press, Oxford, U.K.

Stern, W. L. (2014b). Bulbophyllum -Anatomy. In: A.M. Pridgeon, P.J. Cribb, M.W. Chase, F.N. Rasmussen (Eds.), Genera Orchidacearum, 6, Epidendroideae (Part Three) (pp. 41-43). Oxford University, Oxford, U.K.

Stern, W. L. \& Carlsward, B. S. (2009). Comparative vegetative anatomy and systematics of Laeliinae (Orchidaceae). Botanical Journal of the Linnaean Society, 160(1), 21-41. DOI: 10.1111/j.10958339.2009.00818.x

Teoh, E. S. (2016). Medicinal orchids of Asia. Springer International Publishing, Switzerland.

Thouars, L. (1822). Histoire particulière des plantes orchidées recueillies sur les trois îles australes d'Afrique. de France, de Bourbon et de Madagascar, t. 3.

Yang, S. J., Sun, M., Yang, Q. Y., Ma, R. Y., Zhang, J. L. \& Zhang, S. B. (2016). Two strategies by epiphytic orchids for maintaining water balance: thick cuticles in leaves and water storage in pseudobulbs. AoB PLANTS, 8:plw046; DOI: 10.1093/aobpla/plw046

Yukawa, T. \& Stern, W. L. (2002). Comparative vegetative anatomy and systematics of Cymbidium (Cymbideae: Orchidaceae). Botanical Journal of the Linnaean Society, 138(4), 383-419. DOI: 10.1046/j.10958339.2002.00038.x 